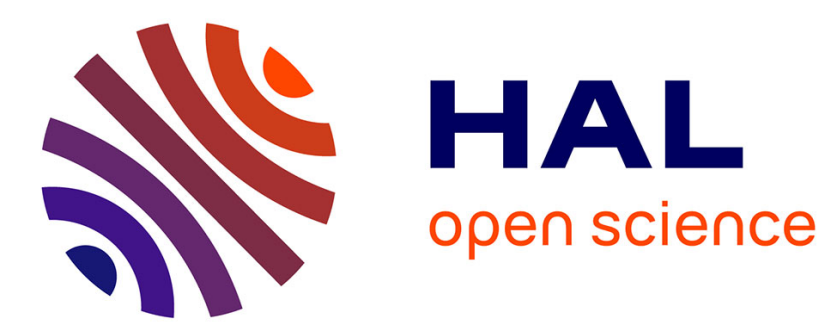

\title{
Phosphorus dendrimers functionalised with nitrogen ligands, for catalysis and biology
}

\author{
Anne-Marie Caminade, Jean Pierre Majoral
}

\section{To cite this version:}

Anne-Marie Caminade, Jean Pierre Majoral. Phosphorus dendrimers functionalised with nitrogen ligands, for catalysis and biology. Dalton Transactions, 2019, 48 (22), pp.7483-7493. 10.1039/c9dt01305a . hal-02147762

\section{HAL Id: hal-02147762 \\ https://hal.science/hal-02147762}

Submitted on 2 Nov 2020

HAL is a multi-disciplinary open access archive for the deposit and dissemination of scientific research documents, whether they are published or not. The documents may come from teaching and research institutions in France or abroad, or from public or private research centers.
L'archive ouverte pluridisciplinaire HAL, est destinée au dépôt et à la diffusion de documents scientifiques de niveau recherche, publiés ou non, émanant des établissements d'enseignement et de recherche français ou étrangers, des laboratoires publics ou privés. 


\section{Phosphorus dendrimers functionalised with nitrogen ligands, for catalysis and biology}

Received 00th January 20xx, Accepted 00th January 20xx

DOI: $10.1039 / x 0 x x 00000 x$

\author{
Anne-Marie Caminade, ${ }^{* a, b}$ and Jean-Pierre Majoral ${ }^{\mathrm{a}, \mathrm{b}}$
}

\begin{abstract}
Phosphorus dendrimers (dendrimers having one phosphorus atom at each branching point) possess versatile properties, depending on the type of their terminal functions. This perspective article focusses on the synthesis and study of properties of phosphorus dendrimers functionalised on their surface by nitrogen ligands and their complexes. It is organized depending on the type of $\mathrm{N}$-ligands ( $\mathrm{P}, \mathrm{N}$ ligands, $\mathrm{N}, \mathrm{N}$ ligands, and $\mathrm{N}, \mathrm{N}, \mathrm{N}$-ligands). Most properties concern catalysis, with palladium, copper, and scandium complexes. Recent advances concern anti-cancer properties, with dendrimers functionalised by copper and gold complexes of N,N-ligands.
\end{abstract}

\section{Introduction}

Organometallic catalysis occupies a major place in homogeneous catalytic processes, and is one of the most significant and important areas of synthetic chemistry. ${ }^{1}$ Among all types of ligands, phosphines are certainly the most widely used since a long time, ${ }^{2}$ because changing the nature of the substituents on the phosphine allows fine-tuning the steric, electronic, kinetic and thermodynamic properties of the complexes, and of their catalytic properties. ${ }^{3}$ However, due to some inherent disadvantages of phosphines (in particular oxidation in air), substitution of $\mathrm{P}$ by other donor atoms like $\mathrm{N}$-containing ligands is an emerging field of catalysis. ${ }^{4}$ Furthermore, nitrogen ligands, unlike phosphine ligands, combine good $\sigma$-donor with $\pi$-acceptor properties, and are thus capable of stabilizing both higher and lower oxidation states of metals. ${ }^{5}$

Supported catalysis is generally considered as heterogeneous catalysis, as the support is generally not soluble. ${ }^{6}$ However, when using dendrimers as supports of catalytic entities, the assembly is generally soluble, and thus affords supported homogeneous catalytic entities. Dendrimers pertain to the large field of polymers, particularly to hyperbranched polymers, but unlike polymers, they are synthesized step-by-step, each new layer emanating from a central core constituting a new "generation". 7 Dendrimers have found different uses in materials chemistry, or biology, ${ }^{8}$ but they have also been frequently used as catalysts. ${ }^{9}$ Most popular types of dendrimers, namely PAMAM (polyamidoamine) ${ }^{10}$ and PPI (polypropylene imine) $^{11}$ are based on nitrogen as branching points. However, "inorganic" dendrimers, ${ }^{12}$ having in particular phosphorus $^{13}$ or silicon ${ }^{14}$ as branching points are also well-known, and have been used in particular as catalysts. ${ }^{15}$

In this Perspective paper, we will focus on the nitrogen ligands grafted on the surface of phosphorus dendrimers (in relation to other dendrimers), and on their properties, in particular as catalysts, but also as anti-cancer agents. It will be organized

\footnotetext{
a. Laboratoire de Chimie de Coordination, CNRS, 205, route de Narbonne, 31077 Toulouse, Cedex 04, France.
}

${ }^{b}$ LCC-CNRS, Université de Toulouse, CNRS, Toulouse, France. depending on the type of $\mathrm{N}$-ligands ( $\mathrm{P}, \mathrm{N}$ ligands, or $\mathrm{N}, \mathrm{N}$, ligands or $\mathrm{N}, \mathrm{N}, \mathrm{N}$-ligands). Several generations of the dendrimers are generally considered, as well as the corresponding monomer. In order to enable a true comparison of the catalytic efficiency, the number of catalytic sites (i.e. of metal atoms) is kept constant within a series of experiments. Besides catalysis, some of these dendrimers have also anti-cancer properties that will be emphasized at the end of this paper.

\section{Synthesis and properties of phosphorus dendrimers functionalised with nitrogen ligands}

Phosphorus dendrimers, in particular phosphorhydrazone dendrimers, ${ }^{16}$ have been synthesized from different cores, but the most widely used is the cyclotriphosphazene. ${ }^{17}$ The repetition of two steps is required to grow the dendrimer. The first step is the substitution reaction of $\mathrm{Cl}$ by 4-hydroxybenzaldehyde in basic conditions, and the second step is the condensation reaction between the aldehydes and the phosphorhydrazide $\mathrm{H}_{2} \mathrm{NNMeP}(\mathrm{S}) \mathrm{Cl}_{2}$ (Scheme 1). The dendrimers can be drawn in two different ways, either the full structure, as illustrated in Scheme 1 for the generation zero (6 aldehydes) and generation $1(12 \mathrm{Cl})$, or a linear structure with parentheses after each branching point, as illustrated for generation 1 (12 aldehydes), and generation 2 (24 Cl or 24 aldehydes). The latter representation will be used all along this paper. The synthesis has been carried out up the $8^{\text {th }}$ generation from the cyclotriphosphazene core, ${ }^{18}$ but it is probably not the highest generation attainable, as the $12^{\text {th }}$ generation has been obtained from a trifunctional core $\left(\mathrm{P}(\mathrm{S}) \mathrm{Cl}_{3}\right)$ using the same synthetic process. $^{19}$

The presence of either $\mathrm{P}(\mathrm{S}) \mathrm{Cl}_{2}$ or $\mathrm{CHO}$ terminal functions, depending on the reaction step considered, is particularly interesting for further functionalisation on the surface of the dendrimers, as they are easily reactive. The $\mathrm{P}(\mathrm{S}) \mathrm{Cl}_{2}$ functions display a versatile reactivity with a large palette of functionalised phenols, but also with functionalised amines. The $\mathrm{CHO}$ terminal functions have been involved in a wide range of condensation reactions, essentially with primary amines and hydrazines. Both types of terminal functions 
have been used for the grafting of ligands, in particular phosphines, ${ }^{20}$ but also $\mathrm{N}$-ligands, as will be illustrated in the following paragraphs.
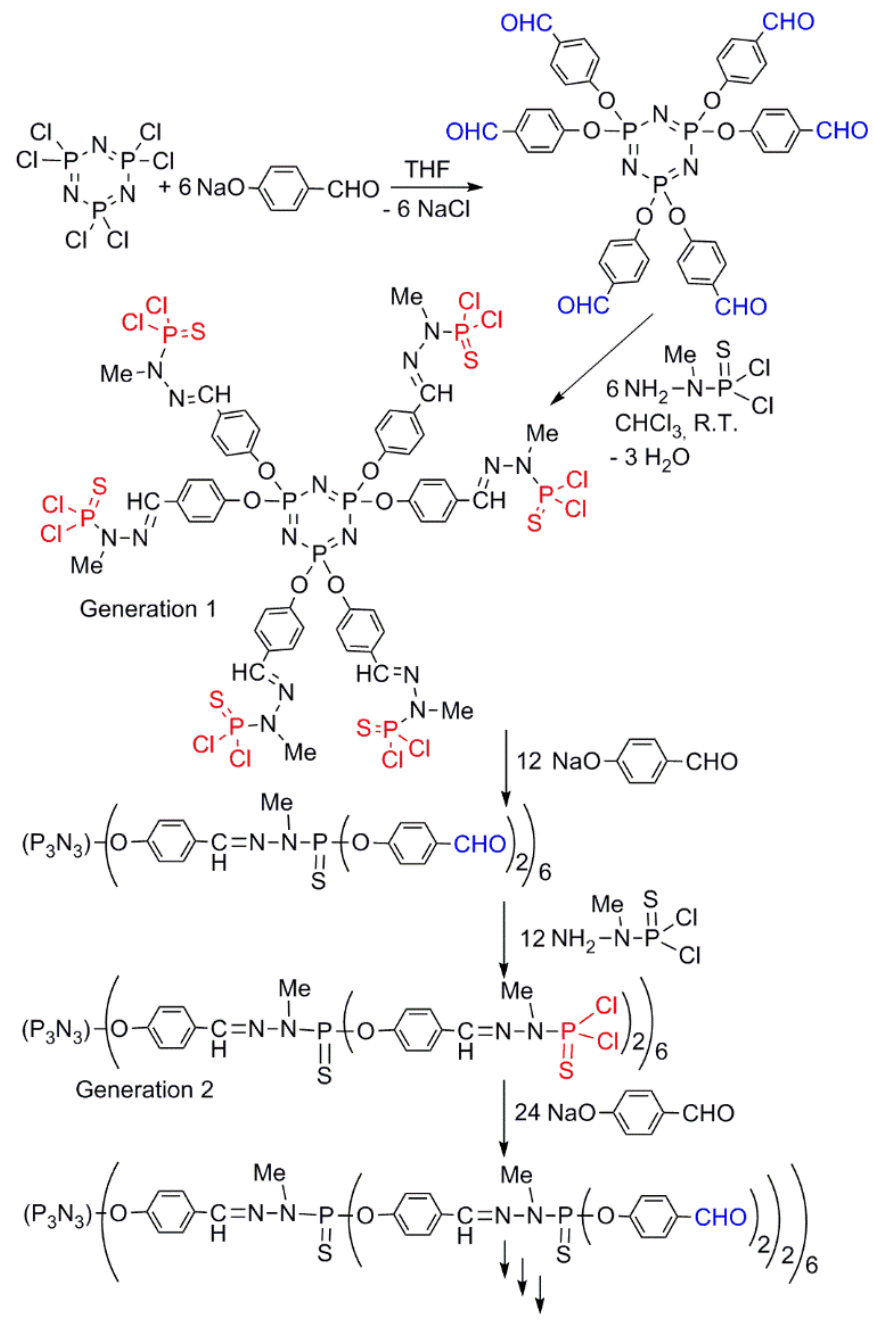

up to Generation 8

Scheme 1. Synthesis of phosphorhydrazone dendrimers from the hexafunctional core $\mathrm{N}_{3} \mathrm{P}_{3} \mathrm{Cl}_{6}$.

\section{$\mathrm{P}, \mathrm{N}$ ligand complexes and their catalytic properties.}

Ligands bearing phosphorus and nitrogen as their donor atoms ( $P, N$ ligands) are widely used. Indeed, this combination can help to stabilize intermediate oxidation states formed during a catalytic cycle. This property is due to the $\pi$-acceptor character of phosphorus that can stabilize a metal centre in a low oxidation state, while the nitrogen $\sigma$-donor ability makes the metal more susceptible to oxidative addition reactions. ${ }^{21}$

The first example of dendrimers functionalised with $P, N$ ligands concerned a phosphorhydrazone dendrimer. It was obtained by grafting a phenol bearing the $P, N$ ligand on the $P(S) C l_{2}$ terminal functions of a first generation dendrimer (Scheme 2). The $\mathrm{PdCl}_{2}$ complex of this dendrimer and of the corresponding monomer was tested in different catalytic Stille coupling reactions (cases a) to c) in Scheme 2). Contrasted results on the efficiency of the catalysis were obtained. Indeed, in case a), the monomer is more efficient than the dendrimer ( $90 \%$ conversion instead of $75 \%)$; in case b), monomer and dendrimer have the same efficiency ( $99 \%$ and $100 \%$ conversion, respectively); and in case c) the dendrimer is more efficient than the monomer ( $98 \%$ instead of $83 \%$ ). Furthermore in the last case, the dendrimer could be recovered and reused two times with a good efficiency $(92 \%$ and $86 \%$ conversion for the second and third runs, respectively). ${ }^{22}$ The same ligand was grafted on the surface of a dendron, and used for complexing $\mathrm{PdCl}_{2}$, but no catalytic experiment was attempted. ${ }^{23}$
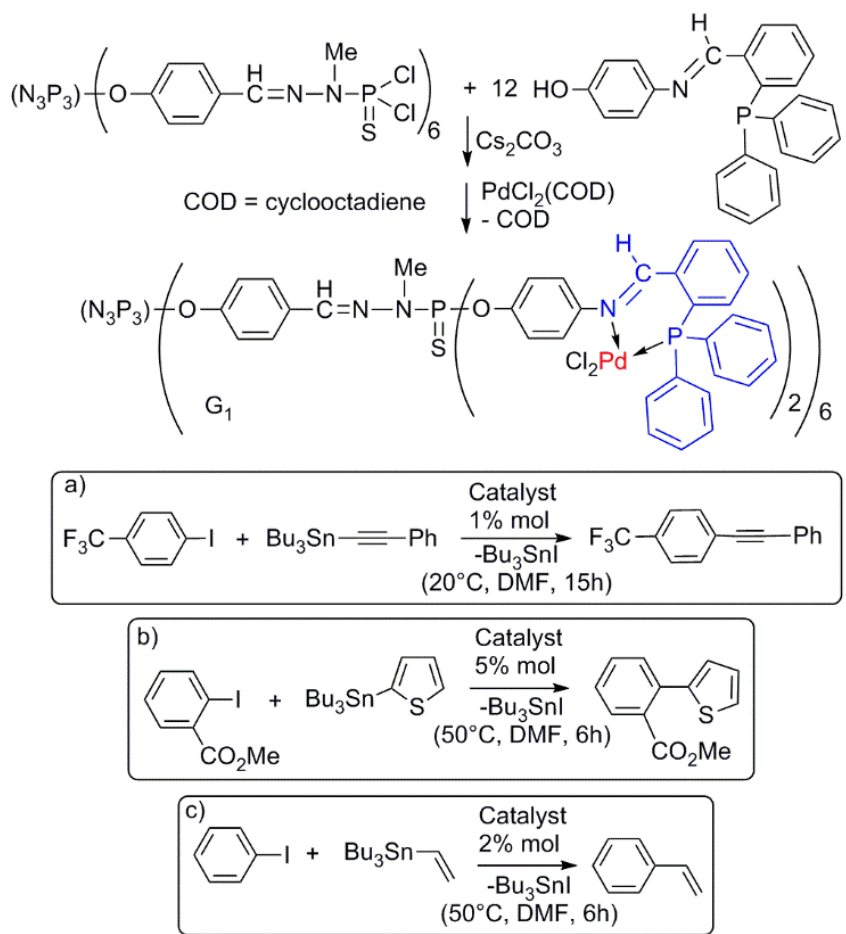

Scheme 2. Synthesis of a $P, N$ complex of a first generation dendrimer, and types of catalysed Stille couplings in which it has been used.

A second example of dendrimers decorated with $P, N$ ligands was obtained by the condensation of (2S)-2-amino-1(diphenylphosphinyl)-3-methylbutane with the aldehyde terminal functions of a third generation dendrimer built from the $\mathrm{P}(\mathrm{S}) \mathrm{Cl}_{3}$ core. Complexation of this dendrimer by $\left[\mathrm{Pd}\left(\eta^{3}-\mathrm{C}_{3} \mathrm{H}_{5}\right) \mathrm{Cl}\right]_{2}$ was carried out in situ to afford a catalyst, used in asymmetric allylic alkylations of rac-(E)-diphenyl-2-propenyl acetate and pivalate (Scheme 3). This compound was one of the best P,N-ligand usable for palladium-mediated asymmetric allylic substitutions, in terms of percentage of conversion (100\%), yield in isolated products (92 to $97 \%$ ), enantiomeric excess ( 89 to $95 \%$ ), and reusability (3 runs with almost the same efficiency). ${ }^{24}$

A third example of $P, N$, ligand was grafted as terminal functions on a dendrimer built from a macrocyclic core. In this case, a $\mathrm{P}, \mathrm{N}$ ligand functionalised by a phenol was first synthesized, then grafted to the $\mathrm{P}(\mathrm{S}) \mathrm{Cl}_{2}$ terminal functions of the dendrimer. In a second step, $\mathrm{PdCl}_{2}$ was complexed on the $P, N$, ligands of the surface of the dendrimer (Scheme 4). However, no catalytic experiment was carried out with this dendritic complex. ${ }^{25}$ Only a few other examples of $\mathrm{P}, \mathrm{N}$ ligands functionalizing dendrimers are known, ${ }^{26}$ based in particular on PPI 
(polypropyleneimine) dendrimers, and used as catalyst for Heck couplings, ${ }^{27}$ or hydroformylations. ${ }^{28}$

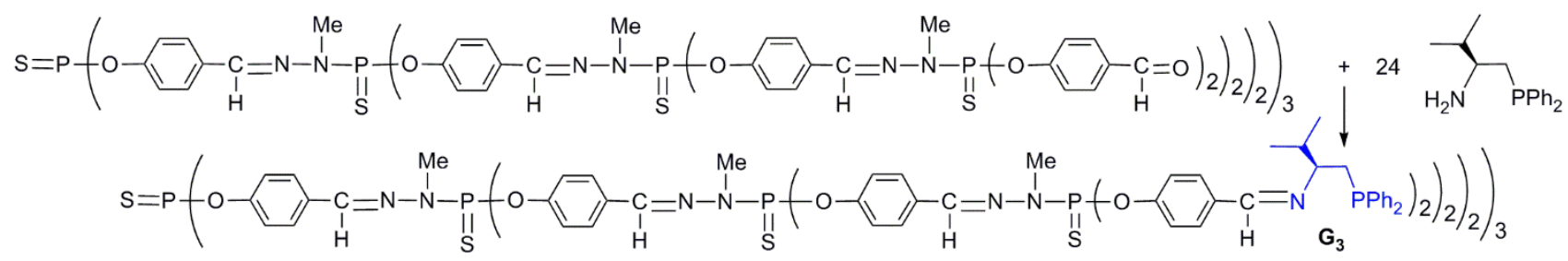

$$
\begin{aligned}
& \mathrm{L}=\text { Imine-phosphine ligand; } \mathrm{R}=\mathrm{MeCO}, \mathrm{tBuCO}, \mathrm{X}=\mathrm{Li}, \mathrm{K} \\
& \mathrm{BSA}=\mathrm{N}, \mathrm{O}-\mathrm{bis}(\text { trimetylsilyl)acetamide } \\
& \mathrm{L} /\left[\mathrm{C}_{3} \mathrm{H}_{5} \mathrm{PdCl}\right]_{2} / \text { Allylester } / \mathrm{CH}_{2}\left(\mathrm{CO}_{2} \mathrm{Me}\right)_{2} / \mathrm{BSA} / \mathrm{XOAC} \\
& 0.05 / 0.025 / 1 / 3 / 0.05
\end{aligned}
$$

$$
\sum_{\mathrm{O} R}^{\mathrm{Ph}}+\mathrm{H}_{2} \mathrm{C}-\text { COOMe }
$$$$
\underset{\text { r. t., } \mathrm{CH}_{2} \mathrm{Cl}_{2}}{\stackrel{\left.\mathrm{LSA} / \mathrm{C}_{3} \mathrm{H}_{5} \mathrm{PdCl}\right]_{2}}{\mathrm{BSOAC}}}
$$

Scheme 3. $A 3^{\text {rd }}$ generation dendrimer bearing $P, N$ ligands, and use of its Pd complex in catalysed asymmetric allylic alkylations.

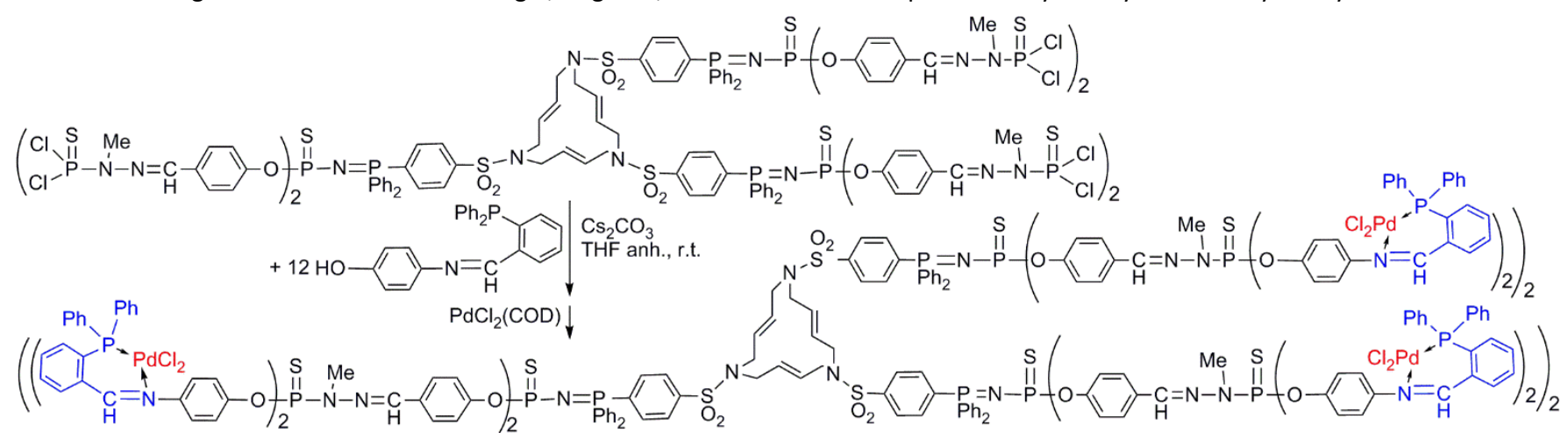

Scheme 4. Synthesis of a P,N ligand complex of a second generation dendrimer built from a macrocyclic core.

\section{$\mathrm{N}, \mathrm{N}$ ligand complexes and their catalytic properties.}

$\mathrm{N}, \mathrm{N}$ ligands (two nitrogen atoms usable for chelating a metal) are dominated by di-imine, pyridine-imine and bipyridine derivatives. ${ }^{29}$ A large number of dendrimers incorporate bipyridine derivatives at the core, ${ }^{30}$ in the branches, ${ }^{31}$ as terminal functions, ${ }^{32}$ or everywhere in the structure. ${ }^{33}$ Some have been used as catalysts, ${ }^{34}$ as well as pyridine-imine derivatives. ${ }^{35}$ The first example of N,N ligand grafted on phosphorhydrazone dendrimers concerned a pyridine-imine functionalised by a phenol, and reacted with the $\mathrm{P}(\mathrm{S}) \mathrm{Cl}_{2}$ terminal functions of generations 1 to 3 . These dendrimers, and the corresponding monomer were then reacted in situ with Cul, and these complexes were used as catalysts in different types of coupling reactions (Scheme 5, cases a) to d)). ${ }^{36}$ Case a) displays Oarylation reactions, carried out by coupling $\mathrm{Phl}$ with $3,5-$ dimethylphenol. The lowest efficiency was observed with the monomer ( $61 \%$ yield). A slight increase was observed with the first and second generations (65 and $69 \%$ yield, respectively), and the best result was obtained with the third generation ( $85 \%$ yield). Case b) in Scheme 5 concerns the coupling of pyrazole with $\mathrm{Phl}$ and $\mathrm{PhBr}$. No reaction was observed with the monomeric complex in both cases. In the case of Phl, all dendrimers afford phenylpyrazole in quantitative yield, in marked contrast with the monomer. In the case of the less reactive bromobenzene, the best results were obtained with the third generation ( $80 \%$ yield), generation 1 (40\% yield) and 2 ( $44 \%$ yield) being less efficient. This reaction was the first example of a clear dendritic effect ${ }^{37}$ in catalysis, i.e. an increase of the catalytic efficiency when the generation of the dendrimer increases, of course as already indicated in the introduction, using the same quantity of metal. Case c) in Scheme 5 displays the coupling of E- $\beta$-Bromostyrene with 3,5-dimethylphenol. Only the monomer and the third generation dendrimer have been tested, affording E-styrylarylether in 35 and $91 \%$ yield, respectively. The same conditions have been applied to the coupling of E- $\beta$ bromostyrene with pyrazole (case d), Scheme 5). E-styrylpyrazole was obtained in $70 \%$ yield with the monomer, and in $100 \%$ yield with the third generation dendrimer. ${ }^{36}$

Another type of $\mathrm{N}, \mathrm{N}$ ligands concerned azabis(oxazoline) derivatives, grafted to the surface of phosphorhydrazone dendrimers, from generations 1 to 3 . Two different families were synthesized; one obtained by grafting a functionalised phenol on the $\mathrm{P}(\mathrm{S}) \mathrm{Cl}_{2}$ terminal functions (case a) Scheme 6), the other from the aldehyde terminal functions, transformed in three step in azide groups, and used in "click" reaction with a functionalised alkyne (case b) in Scheme 6). Copper complexes of both families of dendrimers have been used as catalysts in asymmetric benzoylations. In this type of reaction, starting from a racemic mixture, the maximum yield is $50 \%$. In the first series and for the non-cyclic diol (case c) in Scheme 6), the best results were obtained with the second generation ( $41 \%$ yield, $80 \%$ enantiomeric excess (ee)). In the same conditions, the second series was less efficient concerning the yield $\left(31 \%\right.$, with the $1^{\text {st }}$ generation), but more efficient concerning the ee $\left(86 \%\right.$ with the $2^{\text {nd }}$ generation). The reaction of the cyclic diol (case d)) was carried out only with the second family of the bisoxazoline dendrimers. The best yield was obtained with the third generation dendrimer (39\%), but the best ees were obtained with the $1^{\text {st }}$ and $2^{\text {nd }}$ generation dendrimers (99\% 
in both cases). All dendrimers have been recovered and re-used two times with analogous efficiencies (yield and ee). ${ }^{38}$

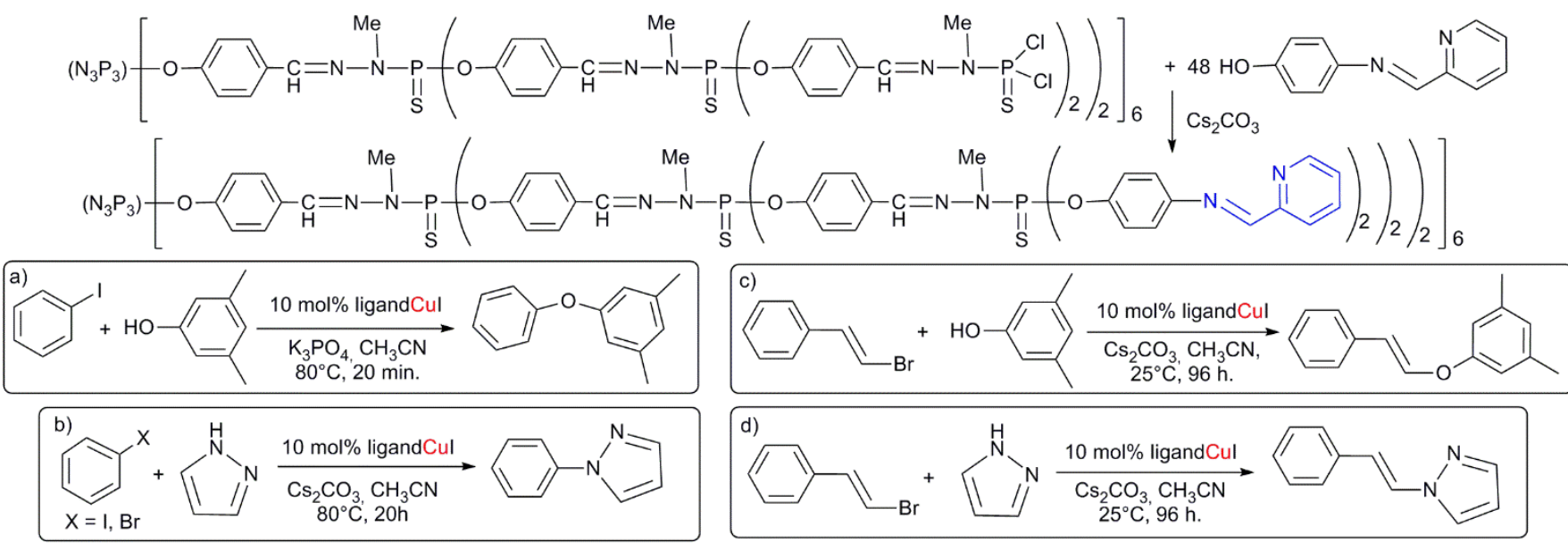

Scheme 5. Synthesis of a N,N ligand of a third generation dendrimer, and use the corresponding Cul complex as catalyst in various coupling reactions. The corresponding monomer, first and second generations of the dendrimer have been also synthesized and used as catalysts.

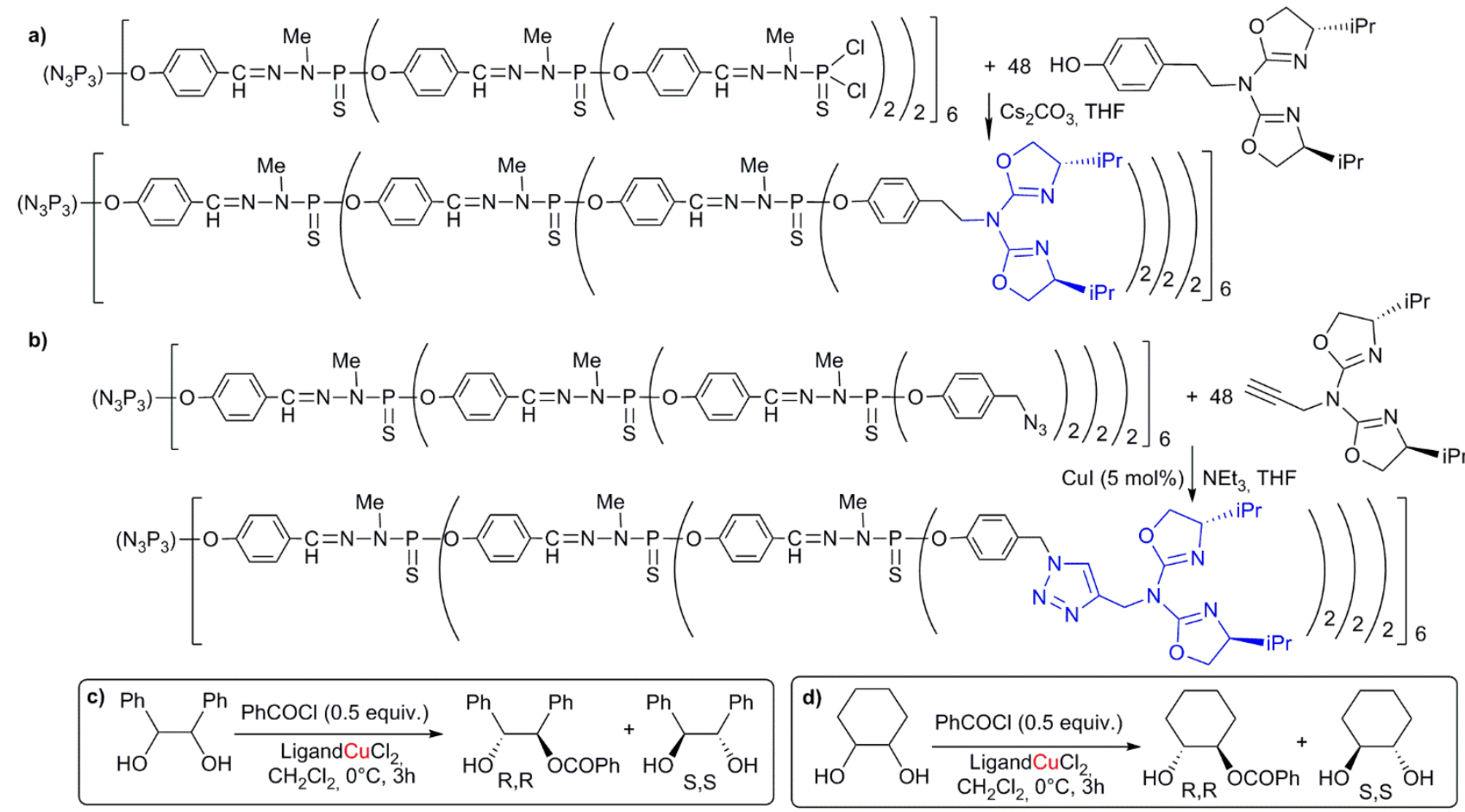

Scheme 6. Two types of azabis(oxazoline) dendrimers, and use of their $\mathrm{CuCl}_{2}$ complexes for catalysing asymmetric benzoylations.

\section{$\mathrm{N}, \mathrm{N}, \mathrm{N}$ ligand complexes and their catalytic properties.}

$\mathrm{N}, \mathrm{N}, \mathrm{N}$ ligands are less frequently used than $\mathrm{N}, \mathrm{N}$ ligands, but they comprise the combination of diversified elements such as pyridine, imine, amine, triazoles, pyrazoles, imidazole, etc. Two types of $\mathrm{N}, \mathrm{N}, \mathrm{N}$ ligands have been grafted on the surface of phosphorhydrazone dendrimers. One is of type "scorpionate", i.e. a tris-2,2,2-(1-pyrazolyl) derivative. ${ }^{39}$ Two methods have been applied to incorporate scorpionates as terminal functions of a first generation dendrimer. The first method (case a) in Scheme 7) is the reaction of a suitably functionalised phenol with the $\mathrm{P}(\mathrm{S}) \mathrm{Cl}_{2}$ terminal groups. The second method starts from the aldehyde terminal functions, transformed in two steps in iodine, to react with the alcohol function of a scorpionate derivative (case b) Scheme 7). The scorpionate first generation dendrimer, after complexation with palladium, was used as catalyst, as well as the corresponding monomer, in Heck (case c)) and Sonogashira (case d)) C-C couplings. The Heck reaction tested concerned the coupling of styrene with iodobenzene. Trans-stilbene was obtained in $24 \%$ yield with the monomeric catalyst, and in $63 \%$ yield with the dendrimer, with $100 \%$ selectivity. The Sonogashira coupling of phenylacetylene with iodobenzene afforded diphenylacetylene in 74 and $73 \%$ yield with the monomer and the dendrimer, respectively. However, the complexation of palladium is more stable with the dendrimer, as a 
mirror of palladium was observed in the case of the monomer, not with the dendrimer. ${ }^{40}$
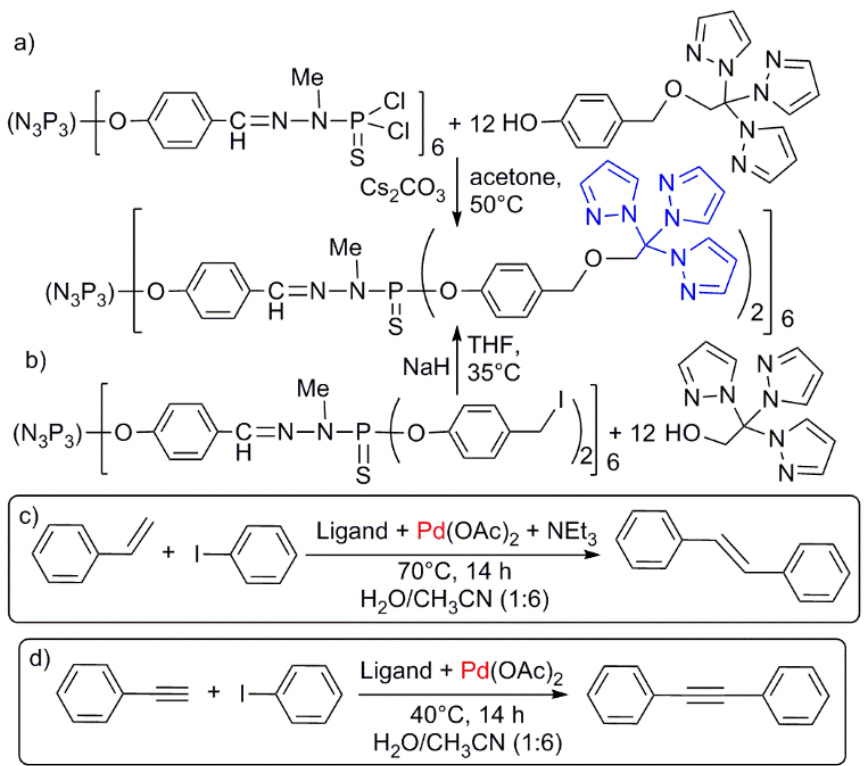

Scheme 7. Two methods of synthesis of a dendrimer decorated with scorpionate ligands, and use of its $\mathrm{Pd}$ complex as catalyst in Heck and Sonogashira C-C couplings.

Another example of $\mathrm{N}, \mathrm{N}, \mathrm{N}$ ligands concerns terpyridine derivatives, for which the metal complexes have interesting catalytic properties. ${ }^{41}$ Several examples of terpyridine ligands grafted on the surface of dendrimers have been published, ${ }^{42}$ but only one concerned catalysis. ${ }^{43} \mathrm{~A}$ terpyridine phenol was grafted as terminal groups on dendrimers (generations 1 to 4 , and monomer), and subsequently complexed with scandium triflate (Scheme 8 ). These complexes were the first example of dendritic terpyridine ligands used as catalysts. They were applied to Friedel-Crafts acylations of aromatics with various electrophiles. The first experiments were carried out in refluxing acetonitrile, but the use of microwave heating enabled to greatly accelerate the reactions (from $16 \mathrm{~h}$ to 15-45 $\mathrm{min}$ ). In the model reaction of anisole with acetic anhydride, the yield in 4-methoxyacetophenone increased from $47 \%$ with the monomer to $80 \%$ with the generation 4 dendrimer, which was found very efficiently recyclable, using diethylether at the end of the reaction to enable the precipitation of the catalyst, and its recovery by filtration. Thus, this generation 4 complex was used in an original type of catalysis. Indeed, the robustness of the $\mathrm{Sc}(\mathrm{OTf})_{3^{-}}$ $\mathrm{G}_{4}$ catalyst, and the efficiency of its recovery and re-use were assessed by changing the substrate at each run. Twelve consecutive reaction cycles were carried out, with no or little loss of activity, as can be seen when comparing the yields in the recycling experiments with the yields obtained for single runs (numbers in parentheses in Scheme 8). ${ }^{44}$

15-membered triazatriolefinic macrocycles are good coordinating agents for $\operatorname{Pd}(0)$ and $\operatorname{Pt}(0)$, forming stable complexes, but also nanoparticles of these elements. ${ }^{45}$ These macrocycles have been functionalised with an amino-ended chain, and then grafted in two different ways on the surface of the dendrimers. The first way was a condensation reaction with the aldehydes end groups of the dendrimers (generations 0,1 , and 4 ), followed by reduction of the imines by $\mathrm{NaBH}_{4}$ (Scheme 9 , case a)). The complexation of these compounds was carried out with $\mathrm{Pd}_{2}(\mathrm{dba})_{4}$ (dba= dibenzylidene acetone) or $\mathrm{Pd}\left(\mathrm{PPh}_{3}\right)_{4}$. Discrete complexes were obtained when using a stoichiometric amount of Pd (one Pd per macrocycle), but the complexation occurs with the double bonds of the macrocycles rather than with the nitrogen atoms. Using an excess of Pd affords $\mathrm{Pd}$ nanoparticles in all cases, probably stabilised also by the $\mathrm{N}$ atoms of the macrocycles. ${ }^{46}$
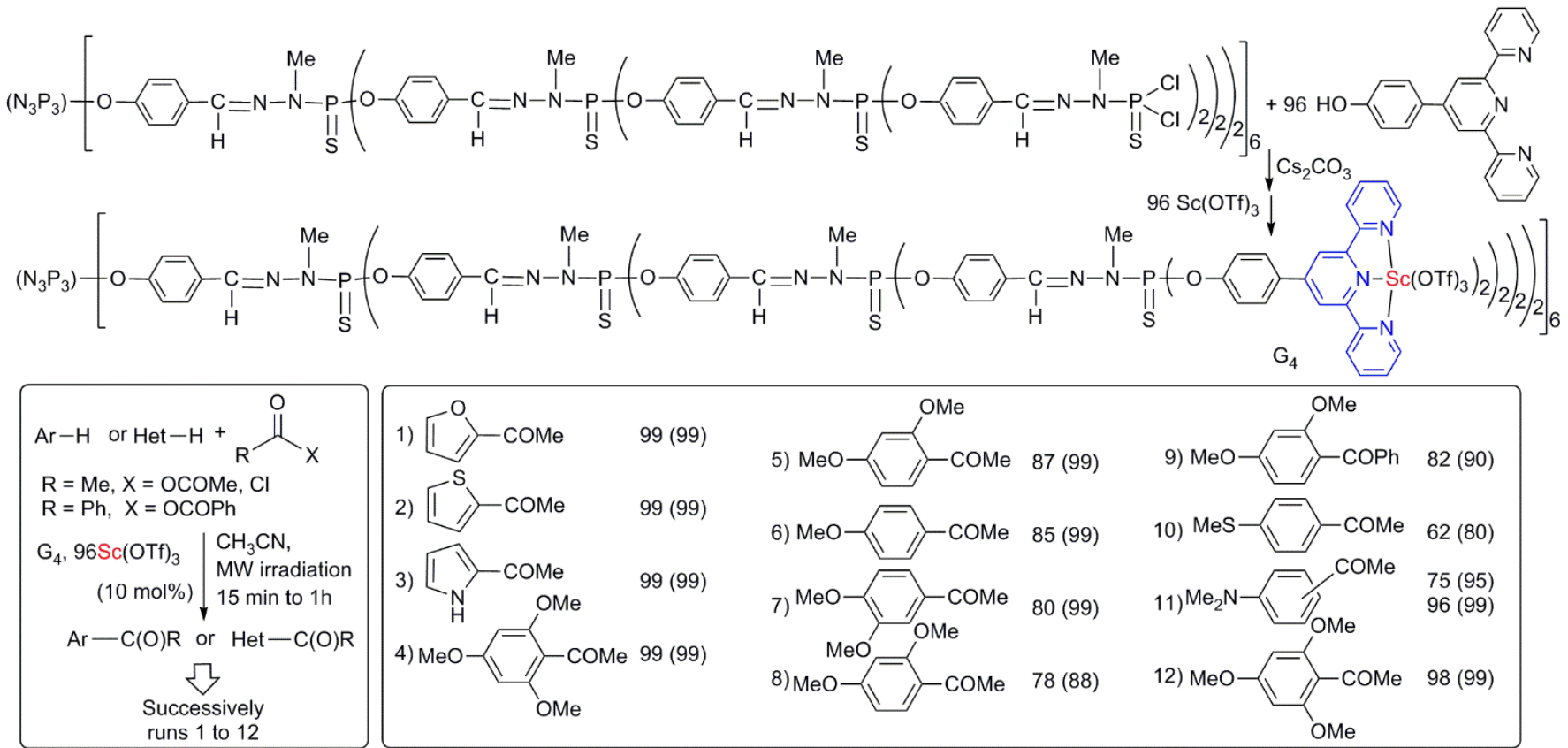

$82(90)$
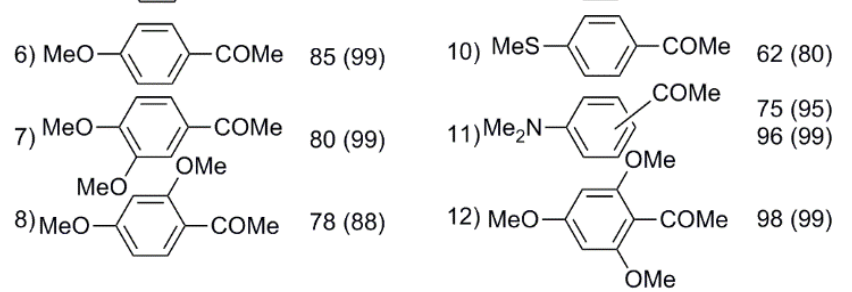

Scheme 8. Generation 4 dendrimer functionalised with terpyridine complexes of Scandium, and its use as catalyst in Friedel- Crafts acylations, under microwave heating. The dendrimer was able to catalyse 12 consecutive runs, even when changing the reagents at each 
step (examples of products obtained in runs 1 to 12 ), and with excellent yields in all cases. For each product, the first number is the yield in the recycling experiment, which is compared with the yield obtained without recycling, indicated in parentheses.
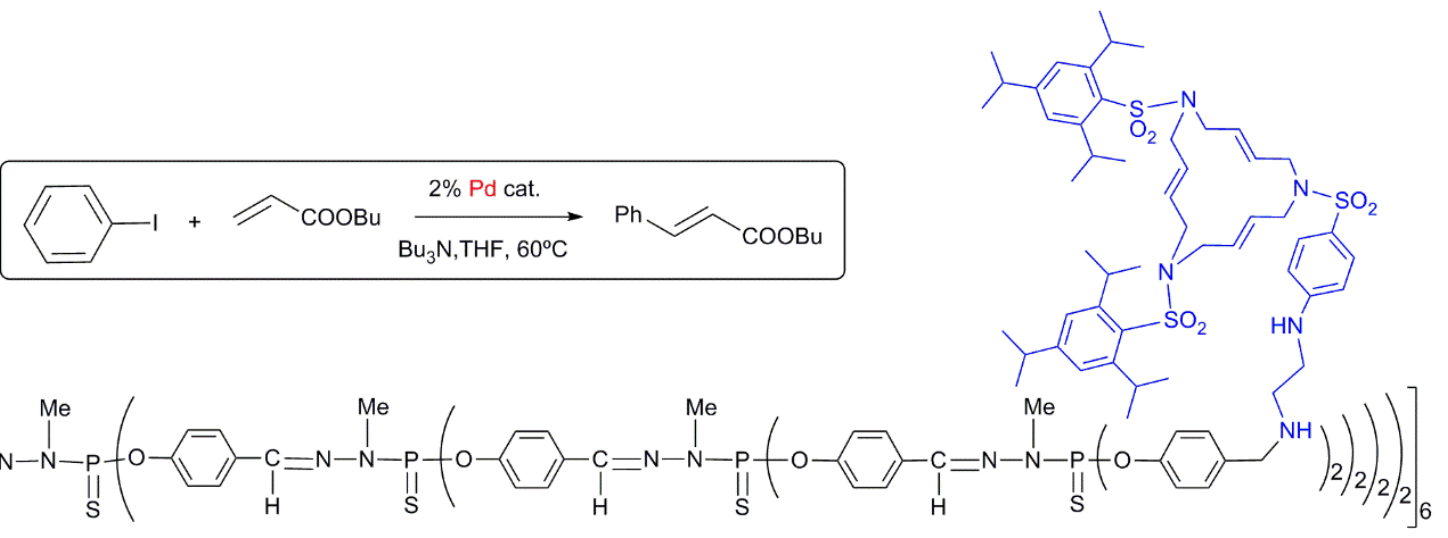

then $\mathrm{NaBH}_{4}$

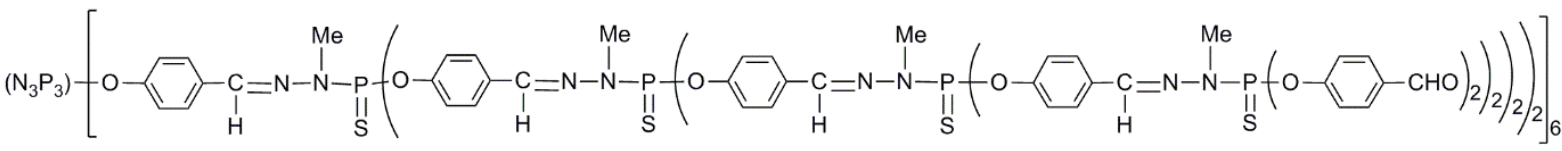<smiles>CC(C)c1cc(C(C)C)c(S(=O)O[Na])c(C(C)C)c1</smiles>

$\left(\mathrm{N}_{3} \mathrm{P}_{3}\right)+\mathrm{C}-\mathrm{Cs}_{2} \mathrm{CO}_{3}$<smiles>C/C=C\CN(C/C=C/CNC/C=C/CN(C/C=C/CN)S(=O)(=O)c1c(C(C)C)cc(C(C)C)cc1C(C)C)S(=O)(=O)c1c(C(C)C)cc(C(C)C)cc1C(C)C</smiles><smiles>C=C(C)Oc1ccc(/C=N/N(C)P(=S)(CC)Oc2ccc([AsH3])cc2)cc1</smiles><smiles>C/C=C(/C)P(C)(=S)N(C)/N=C/c1ccccc1</smiles><smiles>CN(/N=C/c1ccccc1)P(C)(C)=S</smiles><smiles>CN(CCN)P(N)(=S)N(C)/N=C/c1ccccc1</smiles>

Scheme 9. Two methods form grafting triaza triolefinic macrocycles on the surface of dendrimers, and use of the corresponding Pd complex (case a)) for Mizoroki-Heck coupling.

Both the discrete complexes and the Pd nanoparticles have been used as catalysts in Mizoroki-Heck coupling between iodobenzene and n-butyl acrylate (Scheme 9, case a)), and recycling experiments have been carried out 4 times ( 5 runs), using pentane at the end of the reaction to precipitate the catalyst, and recover it by filtration. The discrete generation $0 \mathrm{Pd}$ complex afforded a constant efficiency over the five runs (55-60\% conversion after $4 \mathrm{~h}$.). Surprisingly, the Pd nanoparticles stabilized with the generation 0 dendrimer afforded an increasing efficiency, from $35 \%$ conversion (run 1 ) to $98 \%$ (run 5 ) after $4 \mathrm{~h}$. This phenomenon is less pronounced with the nanoparticles entrapped in the generation 4 dendrimer from $12 \%$ (run 1) to $42 \%$ (run 5). Analyses by TEM (high-resolution transmission electron microscopy) revealed that the size of the nanoparticles decreased with the recycling experiments in the case of generation 0 , but less with generation 4 , in which the nanoparticles are more protected. ${ }^{46}$

The second way to graft the triaza triolefinic macrocycles on the surface of dendrimers consisted in using both amines of the chain to react with the $\mathrm{P}(\mathrm{S}) \mathrm{Cl}_{2}$ functions of the dendrimers, affording a five membered ring incorporating one phosphorus and two nitrogen atoms (Scheme 9, part b). ${ }^{47}$ All generations from 1 to 4 have been synthesized, and then reacted with $\mathrm{Pt}_{2}(\mathrm{dba})_{3}$, affording Pt nanoparticles in all cases. Surprisingly, supramolecular assemblies composed of dendrimers and of coalesced Pt nanoparticles were obtained, in the form of dendritic assemblies. The length of the branches of these assemblies depended linearly on the number of macrocycles per dendrimer, from about $50 \mathrm{~nm}$ with the monomer, to about $350 \mathrm{~nm}$ with generation 4 (48 macrocycles). ${ }^{48}$

\section{$\mathrm{N}, \mathrm{N}$ ligand complexes and their biological properties}

Phosphorus dendrimers have outstanding biological properties in different fields, depending on the type of their terminal functions. ${ }^{49}$ One can cite in particular anti-inflammatory properties with azabisphosphonate terminal functions. ${ }^{50}$ On the other hand, some metal complexes are used as anti-cancer 
drugs, such as the classical cisplatin, carboplatin, oxaliplatin, but also less classical derivatives such as titanocene-based complexes, ferroquine, and other platinum derivatives. ${ }^{51}$ More recent works are based on other metals, such as iron, cobalt, manganese, or copper. ${ }^{52}$

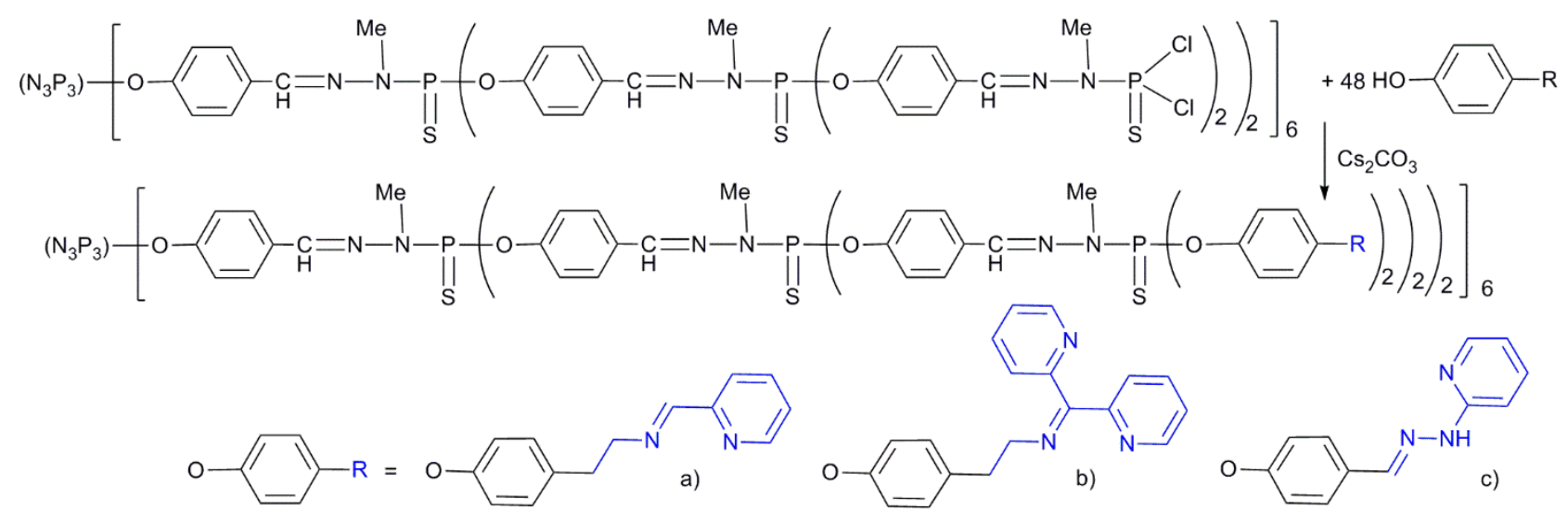

Scheme 10. Diverse types of pyridine imine terminal functions of dendrimers. These dendrimers (generations 1 to 3 ) and their complexes of $\mathrm{CuCl}_{2}$ have anti-cancer properties.

The phosphorus dendrimers shown in Scheme 5, bearing pyridine-imine ligands as terminal functions have good complexing ability towards copper. Thus, other types of pyridine imine terminal functions have been linked to phosphorus dendrimers (generations 1 to 3) (Scheme 10). These dendrimers and their copper complexes $\left(\mathrm{CuCl}_{2}\right)$ have been tested as anti-cancer agents towards both solid tumour KB (epidermal carcinoma) and leukaemia HL60 (promyelocytic) cells. It was shown that the anti-proliferative activity increased i) when the number of terminal functions increased (the third generation is the most efficient), ii) when the compound of the a) family (Scheme 10) is used instead of the other families (b) and c)), and iii) when the copper complexes are used instead of the free ligands. Thus, the third generation bearing the a) type ligands, either free or complexing $\mathrm{CuCl}_{2}$ have been selected for anti-proliferative studies against a panel of tumour cell lines. They display $\mathrm{IC}_{50}$ values ranging from 0.3 to $1.6 \mu \mathrm{M}$ (concentration of dendrimer necessary to kill $50 \%$ of the cells). Interestingly, the copper complex was the most toxic against cancer cell lines and the least toxic against non-cancer cell lines. ${ }^{53}$

In order to understand the difference in the activity of the different pyridine imine complexes, comparative electron paramagnetic resonance (EPR) studies have been carried out. These studies pointed out the particular behaviour of the $\mathrm{Cu}(\mathrm{II})$-conjugated phosphorous-dendrimer of generation 3, decorated with $\mathrm{N}$-(di(pyridine-2-yl)methylene) ethanamine moiety (case a) in Scheme 10), which is the most stable complex. ${ }^{54}$ The mechanism of action of both dendrimers (free and complexed) have been deciphered, and found to be original for anti-cancer agents. Indeed, the free dendrimer moderately activated caspase- 3 activity (a protein playing a major role in cell apoptosis), whereas the copper complex induced a noticeable translocation of Bax (a protein being an anti- or pro-apoptotic regulator) to the mitochondria, resulting in a severe DNA fragmentation, without alteration of the cell cycle. The Cu-conjugated phosphorus dendrimer is more efficient than its non-complexed analogue to activate this pathway, in close relationship with its higher anti-proliferative potency. ${ }^{55}$

Recently, gold (III) has been complexed by the same dendrimer (generation 3, case a)) instead of copper (II), but also a mixture of gold and copper, resulting in a stochastic functionalisation of the surface of the dendrimer. The gold complex is in the form of a salt, with $\mathrm{AuCl}_{4}^{-}$being the counter anion, as shown in Figure 1 for a monomer, which has been characterized by $\mathrm{X}$ ray diffraction. Diverse quantities of $\mathrm{Au}(\mathrm{III})$, from 0 to $100 \%$, have been tested. It was shown that whatever the number of $\mathrm{Au}$ (III) moieties on the surface of the dendrimers, all of them displayed similar potency in the nanomolar range against KB and HL60 cell lines. ${ }^{56}$ In addition to the anti-proliferative activity, the antimicrobial activity of some of these stochastically functionalised dendrimers was tested. Antimicrobial and antifungal activities against several microorganisms in a concentration range of $3.5-500 \mathrm{mg} / \mathrm{L}$ have been observed for all the compounds tested, and marked synergistic effects occur between gold and copper concerning the antifungal activity, which was not observed for the anticancer properties. ${ }^{56}$

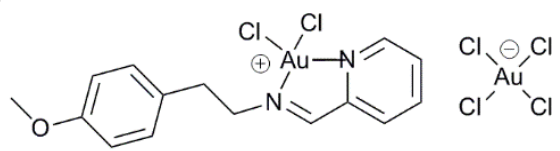

Figure 1. Monomeric structure of the gold complex, identical to the complex on the surface of dendrimers shown in Scheme 10 (case a)).

The anti-cancer properties of a few other types of dendrimers having pyridine imine complexes as terminal functions have been assayed. ${ }^{57}$

\section{Conclusions}

The grafting of ligands, or of any type of functional groups, to dendrimers necessitates first the modification of the ligand 
with a function that should both be suitable for the grafting to the dendrimer, and not have a deleterious effect on the targeted properties. In the case of phosphorhydrazone dendrimers, two main methods have been used, i.e. the addition of phenols to the $\mathrm{P}(\mathrm{S}) \mathrm{Cl}_{2}$, and the condensation reactions of amines (or hydrazines) with the aldehyde terminal groups of the dendrimers. However, other methods have been applied, such as the reaction of amines with the $\mathrm{P}(\mathrm{S}) \mathrm{Cl}_{2}$ functions, and the modification of the aldehyde functions to benzyl alcohol, iodide, azide, or amine, to adapt to the function of the ligands.

The use of dendrimers as supports of $\mathrm{N}$-ligands enable catalyses in homogeneous conditions, but the difference in size of the dendrimers compared to the reagents and products allows to recover and reuse them easily. Such behaviour cannot be observed with monomeric catalysts, illustrating a first advantage when using dendrimers as catalysts. This property is illustrated in particular by the reuse up to 12 times of a dendrimer with the same efficiency (see Scheme 8). ${ }^{44} \mathrm{~A}$ second advantage when using dendritic catalysts is an improved efficiency, compared to the monomers. This efficiency can concern the yield, when no activity is observed with the monomer, whereas an increased yield is observed when the size of the dendrimer increases (see the dendrimers in Scheme 5). ${ }^{36}$ The efficiency can also concern the enantioselectivity, with an example (of phosphine ligand complexes) in which the monomer is a poor catalyst concerning the yield, and affords only a racemic mixture, whereas the dendrimers are both efficient catalysts concerning the yield, and afford the products with ees over $95 \%{ }^{58}$ The third advantage when using dendrimers as catalysts is a decrease in the leaching of metal, as illustrated by a leaching of $\mathrm{Pd}$ over $1400 \mathrm{ppm}$ with a monomeric phosphine complex, and undetectable with the corresponding dendrimeric complex. ${ }^{59}$

Even if phosphines are still the most important class of ligands, nitrogen ligands complexes offer a complementarity for the catalysis of synthetically useful transformations, under mild reaction conditions, as we have illustrated in this perspective review with phosphorhydrazone dendrimers bearing nitrogen ligands as terminal functions. Furthermore, copper complexes of $\mathrm{N}, \mathrm{N}$ pincer ligand, besides having catalytic properties (Scheme 5), ${ }^{36}$ have also anti-cancer properties (Scheme 10), ${ }^{53,56}$ towards a wide range of cancerous cells. In view of these important results in two very different fields of research, we do believe that incorporation of nitrogen ligands within the cascade structure of phosphorus dendrimers or on their surface should lead to applications in other fields of research. One can think in particular to nanomedicine, where they can act in particular as nanocarriers for drugs, DNA, Si-RNA, plasmids, ${ }^{60}$ or as macromolecules active per se, but also to the nanosciences in general.

\section{Conflicts of interest}

There are no conflicts to declare.

\section{Acknowledgements}

Acknowledgements are due to the CNRS for financial support.

\section{References}

1 J. Tsuji, Transition Metal Reagents and Catalysts: Innovations in Organic Synthesis, Wiley, Chichester, 2000; R.H. Crabtree, The Organometallic Chemistry of the Transition Metals, Wiley, USA, 2005.

2 C. A. Fleckenstein and H. Plenio, Chem. Soc. Rev., 2010, 39, 694-711.

3 N. Fey, A. G. Orpen and J. N. Harvey, Coord. Chem. Rev., 2009, 253, 704-722.

4 A. Kumbhar, J. Organomet. Chem., 2017, 848, 22-88.

5 C. J. Elsevier, Coord. Chem. Rev., 1999, 185-186, 809-822.

6 N. Mizuno and M. Misono, Chem. Rev., 1998, 98, 199-217.

7 D. A. Tomalia, A. M. Naylor and W. A. Goddard, Angew. Chem. Int. Ed., 1990, 29, 138-175.

8 A. M. Caminade, C. O. Turrin, R. Laurent, A. Ouali and B. Delavaux-Nicot, Editors, Dendrimers: Towards Catalytic, Material and Biomedical Uses, John Wiley \& Sons Ltd., Chichester, UK, 2011.

9 D. Astruc and F. Chardac, Chem. Rev., 2001, 101, 2991-3023 R. van Heerbeek, P. C. J. Kamer, P. W. N. M. van Leeuwen and J. N. H. Reek, Chem. Rev., 2002, 102, 3717-3756; B. Helms and J. M. J. Frechet, Adv. Synth. Catal., 2006, 348, 1125-1148; A. M. Caminade, P. Servin, R. Laurent and J. P. Majoral, Chem. Soc. Rev., 2008, 37, 56-67; D. Wang and D. Astruc, Coord. Chem. Rev., 2013, 257, 2317-2334.

10 D. A. Tomalia, H. Baker, J. Dewald, M. Hall, G. Kallos, S. Martin, J. Roeck, J. Ryder and P. Smith, Polymer J., 1985, 17, 117-132; A. D. Meltzer, D. A. Tirrell, A. A. Jones, P. T. Inglefield, D. M. Hedstrand and D. A. Tomalia, Macromolecules, 1992, 25, 4541-4548.

11 E. Buhleier, F. Wehner and F. Vögtle, Synthesis, 1978, 78, 155-158; C. Worner and R. Mulhaupt, Angew. Chem.-Int. Edit. Engl., 1993, 32, 1306-1308; E. M. M. de Brabander van den Berg and E. W. Meijer, Angew. Chem.-Int. Edit. Engl., 1993, 32, 1308-1311

12 J. P. Majoral and A. M. Caminade, Chem. Rev., 1999, 99, 845 880; A. M. Caminade, Chem. Soc. Rev., 2016, 45, 5174-5186.

13 N. Launay, A. M. Caminade, R. Lahana and J. P. Majoral, Angew. Chem.-Int. Edit. Engl., 1994, 33, 1589-1592; M. Slany, M. Bardaji, M. J. Casanove, A. M. Caminade, J. P. Majoral and B. Chaudret, J. Am. Chem. Soc., 1995, 117, 9764-9765.

14 L. L. Zhou, N. Hadjichristidis, P. M. Toporowski and J. Roovers, Rubber Chem. Technol., 1992, 65, 303-314; L. L. Zhou and J. Roovers, Macromolecules, 1993, 26, 963-968.

15 A.M. Caminade, A. Ouali, R. Laurent and J.P. Majoral, Inorg. Chim. Acta, 2015, 431, 3-20; A.M. Caminade and R. Laurent, Coord. Chem. Rev., 2019, 389, 59-72.

16 J. P. Majoral and A. M. Caminade, Eur. J. Inorg. Chem., 2019, 1457-1475.

17 A.-M. Caminade, A. Hameau and J.-P. Majoral, Dalton Trans., 2016, 45, 1810-1822; A.-M. Caminade, A. Ouali, A. Hameau, R. Laurent, C. Rebout, B. Delavaux-Nicot, C.-O. Turrin, K. M. Chane-Ching and J.-P. Majoral, Pure Appl. Chem., 2016, 88, 919-929; L. Wang, Y. Yang, X. Shi, S. Mignani, A.-M. Caminade and J.-P. Majoral, J. Mater. Chem. B, 2018, 6, 884895.

18 N. Launay, A. M. Caminade and J. P. Majoral, J. Organomet. Chem., 1997, 529, 51-58.

19 M. L. Lartigue, B. Donnadieu, C. Galliot, A. M. Caminade, J. P. Majoral and J. P. Fayet, Macromolecules, 1997, 30, 73357337. 
20 A. M. Caminade, R. Laurent, B. Chaudret and J. P. Majoral Coord. Chem. Rev., 1998, 178, 793-821; A. M. Caminade, P. Servin, R. Laurent and J. P. Majoral, Chem. Soc. Rev., 2008 37, 56-67; M. Keller, V. Colliere, O. Reiser, A. M. Caminade, J. P. Majoral and A. Ouali, Angew. Chem. Int. Ed., 2013, 52 3626-3629; P. Neumann, H. Dib, A. M. Caminade and E. HeyHawkins, Angew. Chem. Int. Ed., 2015, 54, 311-314.

21 M. P. Carroll and P. J. Guiry, Chem. Soc. Rev., 2014, 43, 819833.

22 M. Koprowski, R. M. Sebastian, V. Maraval, M. Zablocka, V. Cadierno, B. Donnadieu, A. Igau, A. M. Caminade and J. P. Majoral, Organometallics, 2002, 21, 4680-4687.

23 M. Tristany, R. Laurent, H. Dib, L. Gonsalvi, M. Peruzzini, J. P. Majoral and A. M. Caminade, Inorg. Chim. Acta, 2014, 409, 121-126.

24 R. Laurent, A. M. Caminade and J. P. Majoral, Tetrahedron Lett., 2005, 46, 6503-6506.

25 E. Badetti, G. Franc, J. P. Majoral, A. M. Caminade, R. M. Sebastian and M. Moreno-Manas, Eur. J. Org. Chem., 2011, 1256-1265.

26 N. C. Antonels, B. Therrien, J. R. Moss and G. S. Smith, Inorg. Chem. Commun., 2009, 12, 716-719.

27 D. P. Catsoulacos, B. R. Steele, G. A. Heropoulos, M. MichaScrettas and C. G. Screttas, Tetrahedron Lett., 2003, 44, 4575-4578.

28 N. C. Antonels, J. R. Moss and G. S. Smith, J. Organomet. Chem., 2011, 696, 2003-2007.

29 M. E. Cucciolito, V. De Felice, G. Roviello and F. Ruffo, Eur. J. Inorg. Chem., 2011, 457-469.

30 Selected examples: J. Issberner, F. Vogtle, L. DeCola and V. Balzani, Chem.-Eur. J., 1997, 3, 706-712; F. Vogtle, M. Plevoets, M. Nieger, G. C. Azzellini, A. Credi, L. De Cola, V. De Marchis, M. Venturi and V. Balzani, J. Am. Chem. Soc., 1999, 121, 6290-6298; M. C. Haberecht, J. M. Schnorr, E. V. Andreitchenko, C. G. Christopher, M. Wagner and K. Mullen, Angew. Chem. Int. Ed., 2008, 47, 1662-1667; R. Kikkeri, X. Y Liu, A. Adibekian, Y. H. Tsai and P. H. Seeberger, Chem. Commun., 2010, 46, 2197-2199; G. Bergamini, P. Ceroni, P. Fabbrizi and S. Cicchi, Chem. Commun., 2011, 47, 1278012782; M. Vonlanthen, A. Cevallos-Vallejo, E. Aguilar-Ortiz, A. Ruiu, P. Porcu and E. Rivera, Polymer, 2016, 99, 13-20.

31 G. R. Newkome, A. K. Patri and L. A. Godinez, Chem.-Eur. J., 1999, 5, 1445-1451.

32 M. Zhou and J. Roovers, Macromolecules, 2001, 34, 244-252 P. Govender, S. Pai, U. Schatzschneider and G. S. Smith, Inorg. Chem., 2013, 52, 5470-5478; M. Buchert, T. Steenbock, C. Lukaschek, M. C. Wolff, C. Herrmann and J. Heck, Chem.-Eur. J., 2014, 20, 14351-14361.

33 Selected examples: V. Balzani, S. Campagna, G. Denti, A. Juris, S. Serroni and M. Venturi, Acc. Chem. Res., 1998, 31 26-34; P. Ceroni, F. Paolucci, C. Paradisi, A. Juris, S. Roffia, S. Serroni, S. Campagna and A. J. Bard, J. Am. Chem. Soc., 1998 120, 5480-5487; J. Leveque, C. Moucheron, A. Kirsch-De Mesmaeker, F. Loiseau, S. Serroni, F. Puntoriero, S. Campagna, H. Nierengarten and A. Van Dorsselaerc, Chem. Commun., 2004, 878-879; D. N. Lee, B. K. Soh, S. H. Kim, Y. M. Jun, S. H. Yoon, W. Y. Lee and B. H. Kim, J. Organomet. Chem., 2008, 693, 655-666.

34 K. I. Fujita, T. Muraki, H. Hattori and T. Sakakura, Tetrahedron Lett., 2006, 47, 4831-4834; T. Muraki, K. I. Fujita and M. Kujime, J. Org. Chem., 2007, 72, 7863-7870; J. S Willemsen, J. C. M. van Hest and F. Rutjes, Beilstein J. Org. Chem., 2013, 9, 960-965.

35 J. M. Benito, E. de Jesus, F. J. de la Mata, J. C. Flores, R. Gomez and P. Gomez-Sal, Organometallics, 2006, 25, 38763887; J. M. Benito, E. de Jesus, F. J. de la Mata, J. C. Flores and R. Gomez, Organometallics, 2006, 25, 3045-3055; F. Martinez-Olid, J. M. Benito, J. C. Flores and E. de Jesus, Isr. J.
Chem., 2009, 49, 99-108; F. Martinez-Olid, E. de Jesus and J. C. Flores, Inorg. Chim. Acta, 2014, 409, 156-162; T. Ahamad and S. M. Alshehri, Polym. Int., 2014, 63, 1965-1973.

36 A. Ouali, R. Laurent, A. M. Caminade, J. P. Majoral and M. Taillefer, J. Am. Chem. Soc., 2006, 128, 15990-15991.

37 A. M. Caminade, A. Ouali, R. Laurent, C. O. Turrin and J. P. Majoral, Chem. Soc. Rev., 2015, 44, 3890-3899.

38 A. Gissibl, C. Padie, M. Hager, F. Jaroschik, R. Rasappan, E. Cuevas-Yanez, C. O. Turrin, A. M. Caminade, J. P. Majoral and O. Reiser, Org. Lett., 2007, 9, 2895-2898.

39 L. M. D. R. S. Martins and A. J. L. Pombeiro, Coord. Chem. Rev., 2014, 265, 74-88.

40 L. M. D. R. S. Martins, R. Wanke, T. F. S. Silva, A. J. L. Pombeiro, P. Servin, R. Laurent and A. M. Caminade, Molecules, 2018, 23, 3066.

41 A. Winter, G. R. Newkome and U. S. Schubert, Chem CatChem, 2011, 3, 1384-1406.

42 D. J. Diaz, G. D. Storrier, S. Bernhard, K. Takada and H. D. Abruna, Langmuir, 1999, 15, 7351-7354; M. Kimura, K. Mizuno, T. Muto, K. Hanabusa and H. Shirai, Macromol. Rapid Commun., 1999, 20, 98-102; H. J. Murfee, T. P. S. Thoms, J. Greaves and B. Hong, Inorg. Chem., 2000, 39, 52095217; K. Takada, G. D. Storrier, J. I. Goldsmith and H. D. Abruna, J. Phys. Chem. B, 2001, 105, 2404-2411; D. J. Diaz, S. Bernhard, G. D. Storrier and H. D. Abruna, J. Phys. Chem. B, 2001, 105, 8746-8754; C. Kim, K. H. Jung, H. Kim and Y. S. Kwon, Synth. Met., 2005, 153, 269-272; C. Kim and H. Kim, J. Organomet. Chem., 2003, 673, 77-83; D. R. Blasini, S. FloresTorres, D. M. Smilgies and H. D. Abruna, Langmuir, 2006, 22 2082-2089; H. El-Batal, K. Guo, X. P. Li, C. Wesdemiotis, C. N. Moorefield and G. R. Newkome, Eur. J. Org. Chem., 2013, 3640-3644.

43 L. Z. Zeng, C. J. Wang, T. T. Li, X. Gan, C. Li and W. F. Fu, Catal. Commun., 2015, 68, 84-87.

44 A. Perrier, M. Keller, A.M. Caminade, J.P. Majoral and A. Ouali, Green Chem., 2013, 15, 2075-2080.

45 A. Serra-Muns, R. Soler, E. Badetti, P. de Mendoza, M Moreno-Manas, R. Pleixats, R. M. Sebastian and A. Vallribera, New J. Chem., 2006, 30, 1584-1594.

46 E. Badetti, A. M. Caminade, J. P. Majoral, M. Moreno-Manas and R. M. Sebastian, Langmuir, 2008, 24, 2090-2101.

47 G. Franc, E. Badetti, C. Duhayon, Y. Coppel, C. O. Turrin, J. P. Majoral, R. M. Sebastian and A. M. Caminade, New J. Chem., 2010, 34, 547-555.

48 G. Franc, E. Badetti, V. Collière, J. P. Majoral, R. M. Sebastian and A. M. Caminade, Nanoscale, 2009, 1, 233-237.

49 A. M. Caminade, C. O. Turrin and J. P. Majoral, New J. Chem. 2010, 34, 1512-1524; A. M. Caminade, C. O. Turrin and J. P. Majoral, Editors, Phosphorous Dendrimers in Biology and Nanomedicine: Syntheses, Characterization, and Properties, Pan Stanford Publishing, 2018.

50 M. Hayder, M. Poupot, M. Baron, D. Nigon, C. O. Turrin, A M. Caminade, J. P. Majoral, R. A. Eisenberg, J. J. Fournié, A. Cantagrel, R. Poupot and J. L. Davignon, Science Transl. Med. 2011, 3, 81ra35; A. M. Caminade, S. Fruchon, C. O. Turrin, M. Poupot, A. Ouali, A. Maraval. M. Garzoni, M. Maly, V. Furer, V. Kovalenko, J. P. Majoral, G. M. Pavan and R. Poupot, Nature Comm., 2015, 6, 7722.

51 S. van Zutphen and J. Reedijk, Coord. Chem. Rev., 2005, 24 2845-2853; B. W. Harper, A. M. Krause-Heuer, M. P. Grant, M. Manohar, K. B. Garbutcheon-Singh and J. R. AldrichWright, Chem. Eur. J., 2010, 16, 7064-7077.

52 F. Arjmand, Z. Afsan, S. Sharma, S. Parveen, I. Yousuf, S. Sartaj, H. R. Siddique and S. Tabassum, Coord. Chem. Rev., 2019, 387, 47-59.

53 N. El Brahmi, S. El Kazzouli, S. M. Mignani, E. Essassi, G. Aubert, R. Laurent, A. M. Caminade, M. M. Bousmina, T. Cresteil and J. P. Majoral, Mol. Pharm., 2013, 10, 1459-1464. 
54 M. F. Ottaviani, N. El Brahmi, M. Cangiotti, C. Coppola, F. Buccella, T. Cresteil, S. Mignani, A. M. Caminade, J. P. Costes and J.P. Majoral, RSC Adv., 2014, 4, 36573-36583.

55 S. Mignani, N. El Brahmi, L. Eloy, J. Poupon, V. Nicolas, A. Steinmetz, S. El Kazzouli, M.M. Bousmina, M. BlanchardDesce, A.M. Caminade, J.P. Majoral and T. Cresteil, Eur. J. Med. Chem., 2017, 132, 142-156.

56 S. M. Mignani, N. El Brahmi, S. El Kazzouli, R. Laurent, S. Ladeira, A. M. Caminade, E. Pedziwiatr-Werbicka, E. M Szewczyk, M. Bryszewska, M. M. Bousmina, T. Cresteil, J. P. Majoral, Mol. Pharm., 2017, 14, 4087-4097.

57 P. Govender, A. K. Renfrew, C. M. Clavel, P. J. Dyson, B. Therrien and G. S. Smith, Dalton Trans., 2011, 40, 1158-1167; P. Govender, T. Riedel, P. J. Dyson and G. S. Smith, J. Organomet. Chem., 2015, 799-800, 38-44; M. Maroto-Diaz, B. T. Elie, P. Gomez-Sal, J. Perez-Serrano, R. Gomez, M. Contel and F. J. de la Mata, Dalton Trans., 2016, 45, 70497066; S. Michlewska, M. Ionov, D. Shcharbin, M. MarotoDiaz, R. Gomez Ramirez, F. Javier de la Mata and M. Bryszewska, Eur. Polym. J., 2017, 87, 39-47.

58 L. Garcia, A. Roglans, R. Laurent, J. P. Majoral, A. PlaQuintana and A. M. Caminade, Chem. Commun., 2012, 48, 9248-9250.

59 M. Keller, A. Hameau, G. Spataro, S. Ladeira, A. M. Caminade, J. P. Majoral and A. Ouali, Green Chem., 2012, 14, 2807-2815.

60 C. Loup, M. A. Zanta, A. M. Caminade, J. P. Majoral and B. Meunier, Chem.-Eur. J., 1999, 5, 3644-3650; C. Padie, M Maszewska, K. Majchrzak, B. Nawrot, A. M. Caminade and J. P. Majoral, New J. Chem., 2009, 33, 318-326. 